\title{
Research on Air Infiltration Characteristics of High-speed Railway Station
}

\author{
Qian Bin $^{1}$, Sun Liangliang ${ }^{1 *}$, Yu Tao ${ }^{1}$, Lei Bo ${ }^{1}$, Bi Haiquan ${ }^{1}$ \\ ${ }^{1}$ School of Mechanical Engineering, Southwest Jiaotong University, Chengdu 610031
}

\begin{abstract}
High-speed railway station has a large space and a large amount of air infiltration, which has great influences on the thermal load, the thermal environment and the air quality. In this paper, the air infiltration and its distribution characteristics in winter and summer in different climatic zones are determined by $\mathrm{CO}_{2}$ concentration method. The results showed that buoyancy-driven pressure played a dominant role, and the infiltration air volume of $2.8 \mathrm{~h}^{-1}$ in winter is larger than that of $2.0 \mathrm{~h}^{-1}$ in summer. The infiltration air volume in the hot summer and cold winter zone and the hot summer and warm winter zone is larger than that in the cold zone. When the mechanical ventilation system for fresh air is turned off, the indoor $\mathrm{CO}_{2}$ concentration meets the human safety threshold. But it can be found that when the air infiltration volume is small enough to a certain extent, the air infiltration volume has a poor dilutive effect on pollutants in the deeper parts of the station. The tradeoff between the utilization of air infiltration and the elimination of mechanical ventilation needs to be furthered considered.
\end{abstract}

\section{Introduction}

The energy consumption of HVAC system in high-speed railway stations is about $2-3$ times of that of ordinary buildings, accounting for $40 \%-60 \%$ of the total operation energy consumption of high-speed railway station ${ }^{[1-2]}$. Reducing the energy consumption of HVAC system has become the key measures of energy saving for high-speed railway stations. As a typical large open space building, the height of waiting hall of high-speed railway stations can reach more than ten meters. Due to frequent access, external security inspection, passenger flow control and other factors, the entrance is always open for a long time. It results in air infiltration in the high-speed railway stations, which has an important impact on the indoor thermal and humid environment, air quality and energy consumption ${ }^{[3-6]}$. How to measure the infiltration air volume accurately has become an urgent problem to be solved for high-speed railway stations.

Air infiltration is mainly caused by the difference of wind pressure and the buoyancy-driven pressure between inside and outside the building, and the buoyancy-driven pressure and wind pressure interrelate ${ }^{[7]}$. The calculation of wind pressure and buoyancy-driven pressure mainly relies on numerical simulation, and the simulation results of different types of buildings are corrected by the field measurement ${ }^{[8-10]}$. At present, for large space buildings, the influence of air infiltration on the heating and cooling loads cannot be ignored. Field measurement results show that the thermal load caused by the infiltration air from the opening in the upper part of the building can account for $33 \%$ of the total cooling load and $20 \%$ of the total heating load ${ }^{[11]}$. For new buildings, infiltration air is helpful to the dilution of pollutants. With the increase of infiltration air, the increase of pollutant emission factor is greater. Because the number and location of openings of highspeed railway station are not easy to determine, and the operation situation is more complex, it is difficult to determine the volume of infiltration air by numerical simulation. In the past, infiltration air and temperature gradient were tested for a single railway station building, but the current situation of infiltration air for high-speed railway stations with different climate zones and different building forms is not clear ${ }^{[12]}$. In this paper, the $\mathrm{CO}_{2}$ concentration method is used to measure the $\mathrm{CO}_{2}$ concentration and space distribution of 15 high-speed railway stations in five climate zones of China to study the characteristics of infiltration air. The research results provide good references for the design and energy-saving optimization of high-speed railway station building in future.

\section{Measurement method of infiltration air volume}

At present, the calculation methods of infiltration air mainly include tracer gas method, empirical formula calculation method and numerical simulation method. Specific test methods include air velocity test method, $\mathrm{CO}_{2}$ concentration method, moisture content method and heat balance method. Lin Lin of Tsinghua University used the terminal building as the test target to quantitatively analyze the error sources and influencing factors of different test methods and obtained the influencing factors

\footnotetext{
* Corresponding author: sunliangliang@ swjtu.edu.cn
} 
of error and accuracy of different methods ${ }^{[5]}$. As the air velocity of larger than $0.25 \mathrm{~m} / \mathrm{s}$, the indoor and the outdoor $\mathrm{CO}_{2}$ concentration difference of larger than $400 \mathrm{ppm}$, the indoor and outdoor humid ratio difference of larger than $2.8 \mathrm{~g} / \mathrm{kg}$, and indoor and outdoor temperature difference of larger than $2{ }^{\circ} \mathrm{C}$, the calculation errors will not exceed $20 \%$. It can be considered that the calculation result of the air infiltration volume is more accurate than other methods [12].

The openings of high-speed railway station not only exist in the entrance, but also exist in the roof and glass envelope because of insufficient airtightness. The types of indoor heat sources are complex. Hence, the air velocity test method and humid ratio method cannot accurately and effectively calculate the infiltration air volume. Because people can be regarded as the only source of $\mathrm{CO}_{2}$ in the station, $\mathrm{CO}_{2}$, as a tracer gas, can effectively represent the infiltration air volume. In this paper, the $\mathrm{CO}_{2}$ concentration method is used to test the infiltration air volume of high-speed railway stations in different climate zones in winter and summer.

\section{Measurement of $\mathrm{CO}_{2}$ concentration in high-speed railway station}

\subsection{Test object}

To study the characteristics of air infiltration of high-speed railway stations in different zones, according to the energy efficiency design standard for public buildings (GB 50189-2015) [13], 15 large and medium-sized high-speed railway stations are selected to test in five climate zones including severe cold zone (a), cold zone (b), hot summer and cold winter zone (c), hot summer and warm winter zone (d) and mild zone (E). The characteristics of air infiltration in typical days of winter and summer are tested and analyzed, respectively. The selected sample information is listed in Table 1.

Table 1. Information of measured stations

\begin{tabular}{|c|c|c|c|c|c|}
\hline $\begin{array}{l}\text { Weather } \\
\text { zone }\end{array}$ & $\begin{array}{c}\text { Identifier of } \\
\text { station }\end{array}$ & $\begin{array}{c}\text { Area of } \\
\text { station } \\
\left(10^{4} \mathbf{m}^{2}\right)\end{array}$ & $\begin{array}{c}\text { Annual passage } \\
\text { flow } \\
\left(10^{4}\right) \\
\end{array}$ & $\begin{array}{c}\text { Area of waiting } \\
\text { hall } \\
\left(10^{4} \mathbf{~ m}^{2}\right) \\
\end{array}$ & $\begin{array}{l}\text { Height of waiting } \\
\text { hall } \\
\text { (m) }\end{array}$ \\
\hline \multirow{2}{*}{ A } & A1 & 12.0 & 2675 & 2.7 & 30 \\
\hline & $\mathrm{A} 2$ & 6.2 & 1500 & 1.7 & 18 \\
\hline \multirow{4}{*}{ B } & B1 & 10.7 & 2500 & 6.0 & 21 \\
\hline & $\mathrm{B} 2$ & 25.8 & 8546 & 5.0 & 18 \\
\hline & B3 & 10.4 & 892 & 4.1 & 37 \\
\hline & B4 & 6.9 & 649 & 2.5 & 30 \\
\hline \multirow{4}{*}{$\mathrm{C}$} & $\mathrm{C} 1$ & 24.0 & 4486 & 7.8 & 21 \\
\hline & $\mathrm{C} 2$ & 28.2 & 6667 & 8.1 & 33 \\
\hline & $\mathrm{C} 3$ & 10.8 & 4564 & 4.0 & 25 \\
\hline & $\mathrm{C} 4$ & 11.0 & 2448 & 3.4 & 18 \\
\hline \multirow{3}{*}{$\mathrm{D}$} & D1 & 16.8 & 6796 & 7.6 & 20 \\
\hline & D2 & 9.0 & 3650 & 4.3 & 20 \\
\hline & D3 & 6.9 & 680 & / & / \\
\hline \multirow{2}{*}{$\mathrm{E}$} & E1 & 12.0 & 858 & 5.4 & 18.5 \\
\hline & E2 & 11.0 & 2448 & 4.0 & 21 \\
\hline
\end{tabular}

\subsection{Measurement of infiltration air in the station}

The measured parameters mainly includes the outdoor $\mathrm{CO}_{2}$ concentration, the temperature and humidity, and the indoor $\mathrm{CO}_{2}$ concentration, the temperature and the humidity distribution. The measuring positions include the outside of the entrance, the entrance hall and the waiting hall. The layout of the test points is shown in Fig. 1. The outdoor test points are 3-5 $\mathrm{m}$ away from the entrance of the station, and the test points in the waiting hall are evenly selected, including the passenger seat area, aisle gate and other main activity areas.

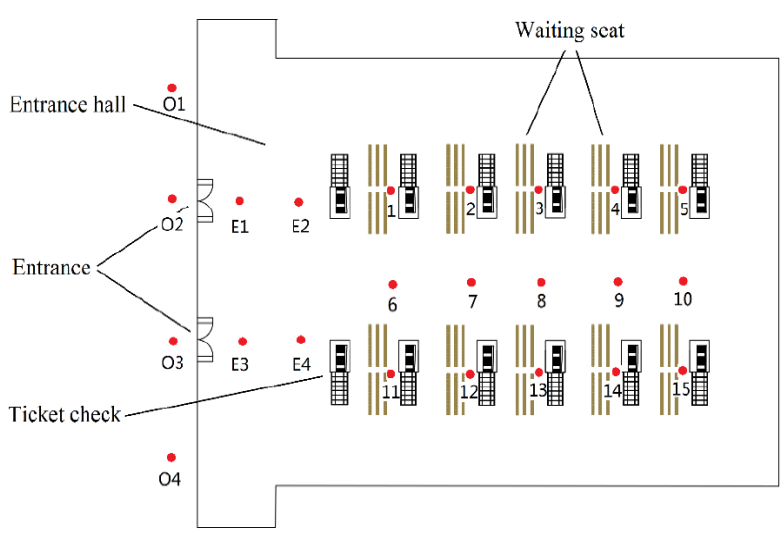

Fig. 1. Test points of typical station

Testo-175 temperature and humidity recorder is used to measure temperature and humidity, and testo- 435 comprehensive analyzer is used to measure $\mathrm{CO}_{2}$ concentration (Fig. 2). The parameters and accuracy of 
instruments are shown in Table 2. The test time is from 8:00 to 18:00 every day, and a group of data is tested every hour. Each group of data is measured five times and the average value is taken. The winter test period is from December 2018 to January 2019, and the summer test period is from July to August 2019.

Table 2. Specification of instrument

\begin{tabular}{ccccc}
\hline Name & Type & Parameter & Accuracy & $\begin{array}{c}\text { Erro } \\
\mathrm{r}\end{array}$ \\
\hline $\begin{array}{c}\text { Temperature } \\
\text { and } \\
\text { humidity } \\
\text { recorder }\end{array}$ & $\begin{array}{c}\text { Testo } \\
425\end{array}$ & $\begin{array}{c}\text { Temperature } \\
\text { and humidity }\end{array}$ & $\begin{array}{c} \pm 0.03 \\
\mathrm{~m} / \mathrm{s}\end{array}$ & $\begin{array}{c}0.02 \\
\mathrm{~m} / \mathrm{s}\end{array}$ \\
\hline $\begin{array}{c}\text { Comprehensi } \\
\text { ve analyzer }\end{array}$ & $\begin{array}{c}\text { Testo } \\
435\end{array}$ & $\begin{array}{c}\mathrm{CO}_{2} \\
\text { concentratio } \\
\mathrm{n}\end{array}$ & $\begin{array}{c} \pm 10 \\
\mathrm{ppm}\end{array}$ & $\begin{array}{c}5.7 \\
\mathrm{ppm}\end{array}$ \\
\hline
\end{tabular}

The main error of $\mathrm{CO}_{2}$ concentration method is that the calculated air volume is higher than that of the actual infiltration air volume without considering the existence of mechanical ventilation. Through the actual measurement and interview, it is found that the high-speed railway station does not turn on the mechanical ventilation on the test day, so the influence of mechanical ventilation can be eliminated. Using the measured data of $\mathrm{CO}_{2}$ concentration, the average infiltration air volume of the station on the test day is calculated.

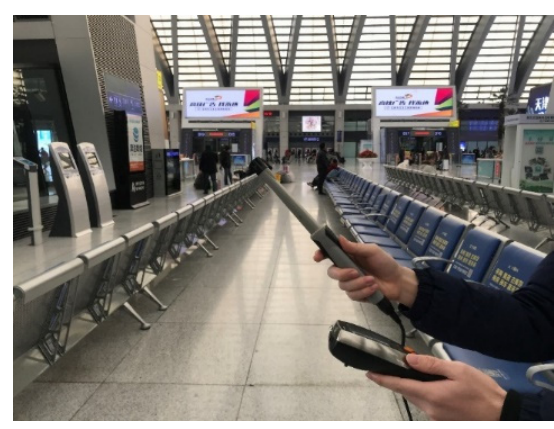

Fig.2 Measurement of $\mathrm{CO}_{2}$ concentration

\section{Characteristics of air infiltration of high-speed railway station}

\subsection{Infiltration air volume}

The indoor and outdoor temperature, $\mathrm{CO}_{2}$ concentration and infiltration air volume of each station in winter and summer are shown in Table 3 and Table 4 . The test results indicate that the equivalent ventilation times of the highspeed railway station are $0.9-6.2 \mathrm{~h}^{-1}$ in winter with an average of $2.8 \mathrm{~h}^{-1}$, and $0.5-4.1 \mathrm{~h}^{-1}$ in summer with an average value of $2.0 \mathrm{~h}^{-1}$. The infiltration air volume in winter is obviously larger than that in summer. The floating phenomenon of hot air is more significant for the building of higher floor height (18-40m). It makes more cold air infiltrating from the bottom opening. The air infiltration in hot summer and cold winter zone (c) and hot summer and warm winter zone (d) is the most obvious. The average air exchange rate is $3.4 \mathrm{~h}^{-1}$ in winter and 2.3 $\mathrm{h}^{-1}$ in summer. The indoor temperature in these zones is lower in winter and higher in summer, which is closely related to the more infiltration air volume.

Table 3. Measured data in winter

\begin{tabular}{cccccc}
\hline No. & $\begin{array}{c}\text { Indoor } \\
\text { temperature } \\
\left({ }^{\circ} \mathrm{C}\right)\end{array}$ & $\begin{array}{c}\text { Outdoor } \\
\text { temperature } \\
\left({ }^{\circ} \mathrm{C}\right)\end{array}$ & $\begin{array}{c}\text { Indoor } \mathrm{CO}_{2} \text { concentration } \\
(\mathrm{ppm})\end{array}$ & $\begin{array}{c}\text { Outdoor } \mathrm{CO}_{2} \text { concentration } \\
(\mathrm{ppm})\end{array}$ & $\begin{array}{c}\text { Air exchange } \\
\text { rate } \\
\left(\mathrm{h}^{-1}\right)\end{array}$ \\
\hline $\mathrm{A} 1$ & 18.5 & -5 & 655.8 & 435.6 & 0.9 \\
$\mathrm{~A} 2$ & 18.7 & -5.3 & 385.4 & 371.7 & 6.2 \\
$\mathrm{~B} 1$ & 15.3 & 1.0 & 552.0 & 474.0 & 1.9 \\
$\mathrm{~B} 2$ & 17.4 & -0.9 & 701.4 & 413.8 & 1.8 \\
$\mathrm{~B} 3$ & 17.7 & 3.6 & 408.3 & 347.6 & 2.9 \\
$\mathrm{~B} 4$ & 18.9 & 4.4 & 509.3 & 449.8 & 1.9 \\
$\mathrm{C} 1$ & 16.1 & 8.8 & 475.0 & 449.8 & 4.2 \\
$\mathrm{C} 2$ & 20.1 & 12.1 & 485.0 & 436.3 & 4.2 \\
$\mathrm{C} 4$ & 16.1 & 4.8 & 317.8 & 276.4 & 5.1 \\
$\mathrm{D} 1$ & 20.1 & 12.1 & 573.7 & 502.3 & 5.6 \\
$\mathrm{D} 2$ & 21.4 & 20.1 & 423.7 & 403.5 & 2.3 \\
$\mathrm{D} 3$ & 18.8 & 20.3 & 552.7 & 520.5 & 2.4 \\
$\mathrm{E} 1$ & 14.0 & 11.9 & 213.3 & 192.3 & 2.2 \\
$\mathrm{E} 2$ & 16.8 & 16.5 & 241.9 & 224.1 & 5.6 \\
\hline
\end{tabular}

The infiltration air volume calculated by $\mathrm{CO}_{2}$ concentration method indicates that there is a huge infiltration air volume in the high-speed railway station. The infiltration air volume of high-speed railway station in hot summer and cold winter zones and hot summer and warm winter zones is significantly greater than that in cold and severe cold zones. The air exchange rate of the former is about 2-3 times of that of the latter, which is also the main reason for the lower indoor temperature of the former in winter. Therefore, in the hot summer and cold winter zones and hot summer and warm winter zones, the equipment selection needs to consider the additional load 
brought by excessive infiltration air to meet requirements of the indoor thermal environment.

Table 4. Measured data in summer

\begin{tabular}{lccccc}
\hline No. & $\begin{array}{c}\text { Indoor } \\
\text { temperature } \\
\left({ }^{\circ} \mathrm{C}\right)\end{array}$ & $\begin{array}{c}\text { Outdoor } \\
\text { temperature } \\
\left({ }^{\circ} \mathrm{C}\right)\end{array}$ & $\begin{array}{c}\text { Indoor } \mathrm{CO}_{2} \text { concentration } \\
(\mathrm{ppm})\end{array}$ & $\begin{array}{c}\text { Outdoor } \mathrm{CO}_{2} \text { concentration } \\
(\mathrm{ppm})\end{array}$ & $\begin{array}{c}\text { Air exchange } \\
\text { rate } \\
\left(\mathrm{h}^{-1}\right)\end{array}$ \\
\hline A1 & 24.6 & 26.3 & 666.5 & 315.0 & 0.7 \\
$\mathrm{~A} 2$ & 24.1 & 25.2 & 362.3 & 247.8 & 2.0 \\
B1 & 26.5 & 27.3 & 469.7 & 395.0 & 1.9 \\
B2 & 26.3 & 29.6 & 603.7 & 340.0 & 1.2 \\
B3 & 23.9 & 24.8 & 388.9 & 291.2 & 1.3 \\
B4 & 24.9 & 25.4 & 409.9 & 283.0 & 2.9 \\
C1 & 25.1 & 26.1 & 409.9 & 393.6 & 0.5 \\
C2 & 24.5 & 25.3 & 773.8 & 448.0 & 3.0 \\
C3 & 24.4 & 24.6 & 498.5 & 418.2 & 3.2 \\
C4 & 24.8 & 24.7 & 523.1 & 485.0 & 2.7 \\
D1 & 30.0 & 33.4 & 534.6 & 318.0 & 1.3 \\
D2 & 28.0 & 37.2 & 586.6 & 290.0 & 1.2 \\
D3 & 27.7 & 37.2 & 452.0 & 292.0 & 1.4 \\
E1 & 24.8 & 25.3 & 377.4 & 366.0 & 4.1 \\
E2 & 23.7 & 24.5 & 349.0 & 313.6 & \\
\hline
\end{tabular}

\section{2 $\mathrm{CO}_{2}$ concentration distribution}

From the perspective of the total amount of infiltration air, the fresh air brought by air infiltration far exceeds the fresh air demand of personnel. In recent years, the viewpoint of canceling mechanical fresh air has been widely discussed, but there is a lack of practical verification and data. Compared with mechanical fresh air, infiltration air is unstable in time distribution and uneven in space distribution. While using $\mathrm{CO}_{2}$ concentration method to calculate the infiltration air volume, to explore the influence of air infiltration on the diffusion of fresh air in the building, this paper analyzes the $\mathrm{CO}_{2}$ concentration distribution in the waiting floor area of high-speed railway station. During the statistics, the average $\mathrm{CO}_{2}$ concentration of seven positions selected in the station waiting floor according to the north-south direction (some stations in the east-west direction) is compared and analyzed, and the results are shown in Fig. 3.

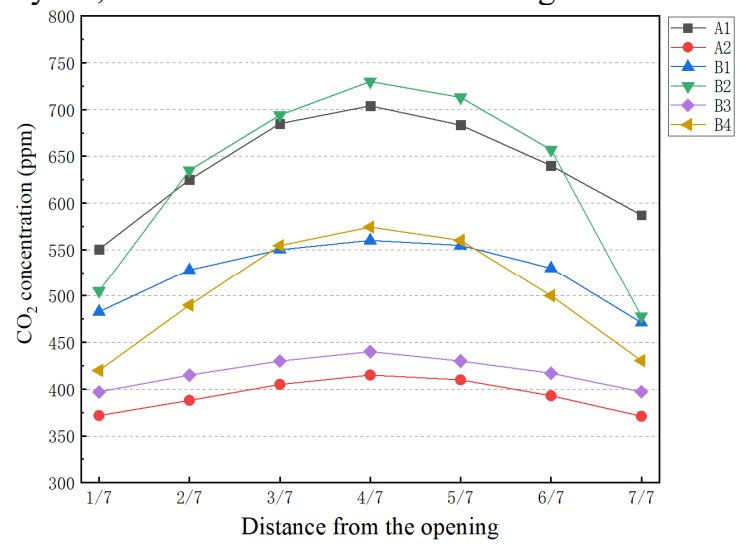

(a) Severe cold zone and cold zone

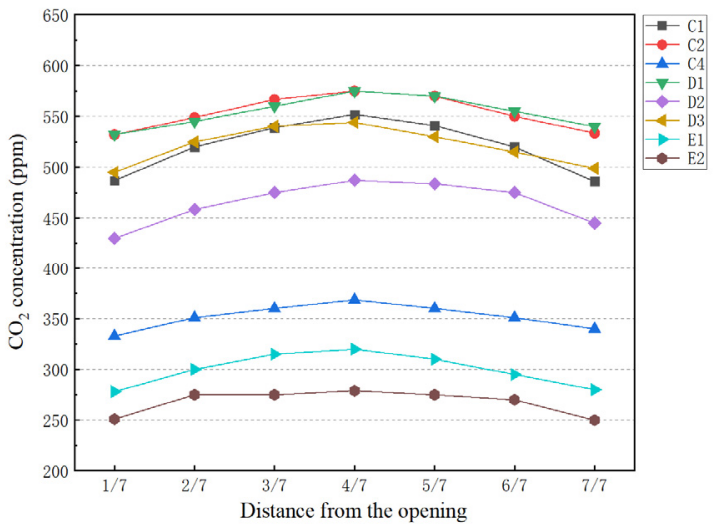

(b) Severe cold zone and cold zone

Fig. 3 Measured data of $\mathrm{CO}_{2}$ concentration

The distribution of $\mathrm{CO}_{2}$ concentration in the station is positively correlated with the distance from the opening. Under the same air exchange rate, the uniformity of $\mathrm{CO}_{2}$ concentration in severe cold zone and cold zone is lower than that in hot summer and cold winter zone and hot summer and warm winter zone, which is related to the air tightness and the temperature difference between indoor and outdoor air. Due to the different structural characteristics of the station, glass houses are often set at the entrances and exits of the station in cold and severe zones as buffer zones; while the station entrances in hot summer and cold winter zone, hot summer and warm winter zone and mild zone are single-layer doors and always open, so the indoor $\mathrm{CO}_{2}$ concentration of the latter zones is lower and more evenly distributed.

During the test, the mechanical fresh air system in the station is basically not turned on. On one hand, the outdoor temperature is too low in winter in severe cold zone and cold zone, and the introduction of mechanical fresh air will cause equipment damage. On the other hand, a large amount of infiltration air makes the unit unable to ensure the normal indoor thermal environment. Due to the introduction of infiltration air, the $\mathrm{CO}_{2}$ concentration in the station is far lower than the safety threshold of human body (1000ppm). In hot summer and cold winter zone and 
hot summer and warm winter zone, the infiltration air volume can meet the demand of fresh air and ensure the uniformity of fresh air, but excessive fresh air will increase the thermal load of HVAC system. With the increase of air tightness, the influence distance of air infiltration gradually weakens, and the passenger flow in the middle of the station is often the largest. Therefore, when the infiltration air volume is less than a certain degree, the dilution effect of $\mathrm{CO}_{2}$ and other pollutants in the middle of the station will be insignificant. The air quality will be improved only at the entrance and exit. Hence, whether the mechanical fresh air can be replaced by infiltration air remains to be discussed.

\section{Conclusions}

In this paper, the infiltration air volume of high-speed railway station in different climate zones is obtained by measurement and calculation. Combined with the indoor $\mathrm{CO}_{2}$ concentration distribution, the following conclusions are obtained:

(1) There are a great deal of infiltration air volume in the high-speed railway station. Under the leading role of buoyancy-driven pressure, the infiltration air volume in winter is generally larger than that in summer. In winter, the equivalent air exchange rate of infiltration air is 0.9 $6.2 \mathrm{~h}^{-1}$, with an average of $2.8 \mathrm{~h}^{-1}$. In summer, the equivalent air exchange rate is $0.5-4.1 \mathrm{~h}^{-1}$, with an average of $2.0 \mathrm{~h}^{-1}$. The infiltration air volume in hot summer and cold winter zone and hot summer and warm winter zone is higher than that in severe cold zone and cold zone, in which the average equivalent air exchange rate in hot summer and cold winter zone and hot summer and warm winter zone is $3.4 \mathrm{~h}^{-1}$ in winter and $2.3 \mathrm{~h}^{-1}$ in summer.

(2) When the mechanical fresh air is not turned on, the infiltration air volume in the station can meet the fresh air demand of the personnel. With the increase of air tightness, the uniformity of $\mathrm{CO}_{2}$ concentration decreases. The maximum $\mathrm{CO}_{2}$ concentration in severe cold zone and cold zone is much larger than that in other zones. The main reason is that the air tightness in these two zones is better. The penetration distance of the air infiltration is shorter, and the dilution effect of pollutants in the middle of the waiting hall is weaker.

(3) The fresh air brought by air infiltration is uneven and unstable. When the infiltration air volume is lower than a certain value, even if the infiltration air volume is equivalent to the mechanical ventilation volume, its dilution effect on pollutants in the deeper area is quite limited. Therefore, the tradeoff between the control of infiltration air volume and the cancellation of mechanical fresh air needs to be further studied.

\section{Acknowledgments}

This research work was financially supported by the "National Key R\&D Program of China" (No.2018YFC0705000) and "Sichuan Science and Technology Support Program” (2019YFG0055).

\section{References}

1. Yang L, Xia J, Procedia Engineering, 121, 1887-1893 (2015)

2. Building Energy Research Center, Tsinghua University, China Architecture \& Building Press, 12 (2018)

3. Zhang T, Liu XC, Liu XH, et al, HVAC, 48, 53-59 (2018)

4. Zhao JG, Yu JH, Yang QC, et al, Building Thermal Energy Ventilation and Air Conditioning, 38, 15-18 (2019)

5. Lin L, Liu XC, Zhang T, et al, Building Science and Technology, 34, 13-21 (2018)

6. Zhou YL. Southwest Jiaotong University, 2008.

7. Yang JG, Huang C, Power Generation and Air Conditioning, 23, 20-23 (2002)

8. Qiu GC, HVAC, 41-49 (1976)

9. Zou ZS. National HVAC Academic Conference of Railway and Urban Rail, 2016.

10. Yang WC, HVAC, 6-10 (1986)

11. Zhao RY, Fan CY, et al, Beijing: China Architecture \& Building Press, 303 (1994)

12. Liu JG, Zhu YX, Zhang YF, et al, Dynamic (Eco-city and Green Building), 107-111 (2012)

13. Ministry of Housing and Urban-Rural Development of the People's Republic of China.. China Architecture \& Building Press, 2015. 